\title{
Intensity Analysis Method for Measurement the Damage Severity of Concrete Structure by Utilizing the Acoustic Emission Technique
}

\author{
Shahiron Shahidan, Norazura Muhamad Bunnori, Neeraj Bhardwaj, Noorsuhada Md \\ Nor, Siti Ramziah Basri, and Sakhiah Abdul Kudus
}

\begin{abstract}
Evaluation methods such as acoustic emission (AE) are required for assessing the deterioration on concrete structures. This paper gives a brief on the evaluations of the acoustic emission to the health monitoring of reinforced concrete structure beam. Small scale size beam have been used for this investigation and the $\mathrm{AE}$ signal processing are the main principal data in this work for assessing by using the statistical technique, which is known as intensity analysis method (IA). This technique is capable to quantify and evaluate the damage severity on concrete structures. Eventually, by using the $\mathbf{A E}$ signal strength data, the results indicates are greater instruments in determining the damage mechanism level on concretes structure.
\end{abstract}

Index Terms - Acoustic emission, intensity analysis, historical index, severity index.

\section{INTRODUCTION}

Ordinary, reinforced concrete structures have been utilized around the world since the ancient time and basically the applications are more into buildings, bridges, and dam. Even nowadays, the popularity of the reinforced concrete structure applications has been maintained as a major and minor construction [1]-[4]. Upon to that matter, it has been facing several types of damages mechanisms and deteriorations during their service life. Therefore, their maintenance are becomes more significant part for evaluation and to preserve the integrity of structure.

In such deteriorations are the increments loading of structure due to the increasing of traffic flow and severe environmental effects such as, scaling, spall and corrosion. Therefore the process of the damages mechanisms on concrete will induced the interaction of duration between long term and short term process.

In order to maintain the structural integrity and monitor the defects in the concrete structure, nondestructive testing (NDT) is an effective method for investigation and evaluation the

Manuscript received November 10, 2011; revised December 20, 2011.

This work was supported by the Ministry of Higher Education, Government of Malaysia,(ERGS and PRGS) School of Civil Engineering, Universiti Sains Malaysia and Universiti Tun Hussien Onn

S. Shahidan, N. M. Bunnori, N. Bhardwaj, , S. R. Basri, and S. A. Kudus are with School of Civil Engineering, Engineering Campus, Universiti Sains Malaysia (USM), Seri Ampangan, Seberag Perai Selatan, 14300 Nibong Tebal, Pulau Pinang, Malaysia(email: shahironshahidan@gmail.com, cenorazura@eng.usm.my, ramziah88@yahoo.com.my, sakhiah88@ymail.com)

N. Md Nor is with Faculty of Civil Engineering, Universiti Teknologi MARA (UiTM), 40450 Shah Alam, Selangor, Malaysia (email:idanur211@yahoo.com). actual condition of structures [5]. One of the excellent techniques in the various types of NDT methods are Acoustic Emission (AE) [6], [7].

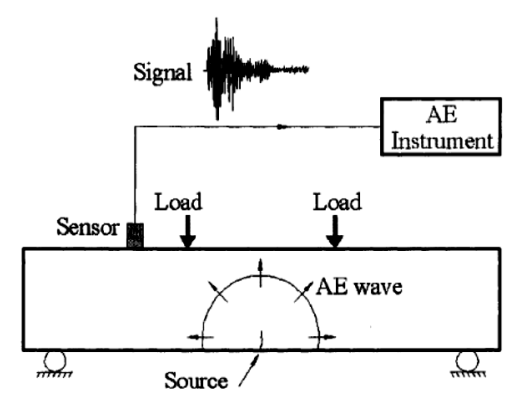

Fig. 1. Principle of AE[2].

This paper involves the application of $\mathrm{AE}$ technique as a NDT monitoring to measure the damage severity of the reinforced concrete beam. Throughout this research, IA method was utilized for analyzing the AE signal strength data.

\section{FUNDAMENTAL OF AE}

The term of $\mathrm{AE}$ is defined as the class of phenomena whereby transient elastic waves are generated by the rapid release of energy from localized sources within a material [8]. Today, AE technique was found to be the most efficiency and powerful tool in NDT for real time testing of the materials behavior deforming under stress and was established for damaged detection and monitoring of concrete structure [9]-[13].

Basically AE will produced the transient wave from the propagation and generations of cracking and stress in material respectively. This was revealed in the Figure 1, the principle of $\mathrm{AE}$ technique in concrete beam under stress condition

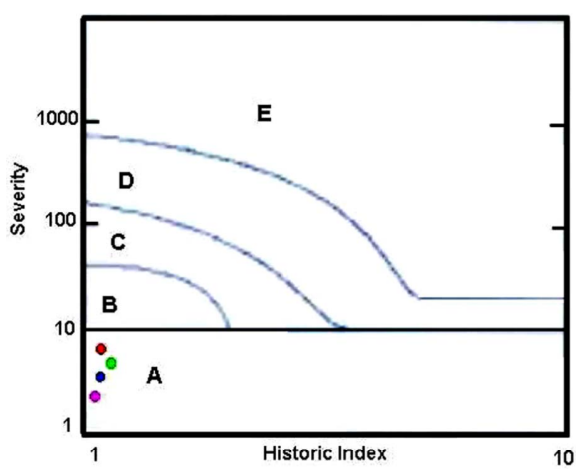

Fig. 2. Typical Intensity Chart for Bridge[16]. 
TABLE I: SIGNIFICANCE OF INTENSITY ZONE [17]

\begin{tabular}{|c|c|}
\hline Zone Intensity & Recommended Action \\
\hline A-No significant emission & Insignificant acoustic emission \\
\hline B- Minor & $\begin{array}{c}\text { Note for reference in future tests. } \\
\text { Typically minor surface defects such as } \\
\text { corrosion, pitting, gouges or crack } \\
\text { attachments welds. }\end{array}$ \\
\hline C & $\begin{array}{c}\text { Defects requires follow-up evaluation. } \\
\text { Evaluation may be based on further data } \\
\text { analysis or complementary } \\
\text { nondestructive examination. }\end{array}$ \\
\hline D & $\begin{array}{c}\text { Significant defect requires follow-up } \\
\text { inspection. }\end{array}$ \\
\hline E & $\begin{array}{c}\text { Major defect requires immediate } \\
\text { shut-down and follow-up inspection }\end{array}$ \\
\hline
\end{tabular}

\section{INTENSITY ANALYSIS METHOD}

Mathematically, Intensity analysis (IA) method is the technique that evaluates the integrity of structural significance for AE event as well as the level of deterioration of a structure by calculating two values which are called historic index (HI) and severity $\left(S_{r}\right)$ [14]. According to [10], this quantification method is known as the statistical analysis and it has been successfully utilized to FRP, metal, and concrete for evaluation system.

The equations for Historical Index and Severity have been shown in Eq. 1 and Eq. 2[10,15]:

$$
H(I)=\frac{N}{N-K} \cdot\left(\frac{\sum_{i=K+1}^{N} S_{o i}}{\sum_{i=1}^{N} S_{o i}}\right)
$$

where, $\mathrm{H}(\mathrm{I})$ : Historic Index, $\mathrm{N}$ : Number of hits up to time $\mathrm{t}$, $\mathrm{S}_{\mathrm{oi}}$ : Signal strength of the $i$ th hit, For concrete: $\mathrm{K}=0, \mathrm{~N} \leq 50$; $\mathrm{K}=\mathrm{N}-30,51 \leq \mathrm{N} \leq 200 ; \mathrm{K}=0.85 \mathrm{~N}, 201 \leq \mathrm{N} \leq 500$.

$$
\mathrm{S}_{\mathrm{r}}=\frac{1}{\mathrm{~J}} \cdot\left(\sum_{\mathrm{m}=1}^{\mathrm{J}} \mathrm{S}_{\mathrm{om}}\right)
$$

where, $\mathrm{S}_{\mathrm{r}}$ : Severity index, for concrete material $\mathrm{J}: \mathrm{J}=0, \mathrm{~N}<$ $50 ; \mathrm{J}=50, \mathrm{~J} \geq 50, \mathrm{~S}_{\mathrm{om}}$ : signal strength of the $m$ th hit where the order of $\mathrm{m}$ is based on magnitude of the signal strength.

Therefore, the $\mathrm{S}_{\mathrm{r}}$ and maximum $\mathrm{HI}$ value will be plotted on the intensity chart as presented in Fig. 2.

The chart is divided into intensity zones which indicate the structural significance of the emission. All of the zones descriptions are presented in TABLE I.

\section{EXPERIMENTAL WORK AND AE INSTRUMENTATION}

Throughout this laboratory work Small scale beam size, cross section $100 \mathrm{~mm}$ X $100 \mathrm{~mm}$ and length $500 \mathrm{~mm}$ were included in this investigation and tested by three points bending. It was reinforced with high tensile strength size $2 \mathrm{~T} 10$ and the steel bar was hanger with mild tensile strength of 2T8, while as for the size of stirrups is R6 that has been normally used in the small scale size. The cross section detailing for all categories have been indicated in Fig. 3 .

Hydraulic jet and load cell have been installed in the middle of the beam and it consider as a Loading partition $(\mathrm{P})$. The side surface of the beam specimens have been grinding and clean smoothly for applying the sensors type R6I Physical Acoustic Corporation (PAC).

Therefore after completing all the setting up of the AE instrumentation and AE Win software, the sensitivity of the sensor need to be check for the data accuracy. This method normally known as Hsu-Nielsen source method [8] After that the threshold setting was fixed up to 45 decibel (db) and the data hit parameters were setting up for all component such as, amplitude, frequency, signal strength, absolute energy, rise time and duration.
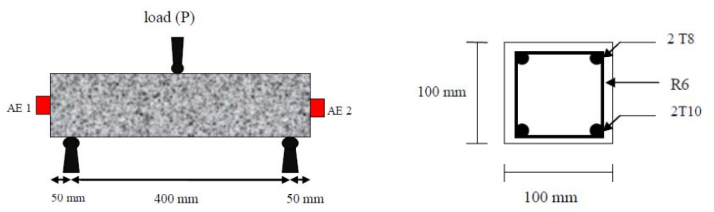

Fig. 3. Testing procedure and detail dimension.

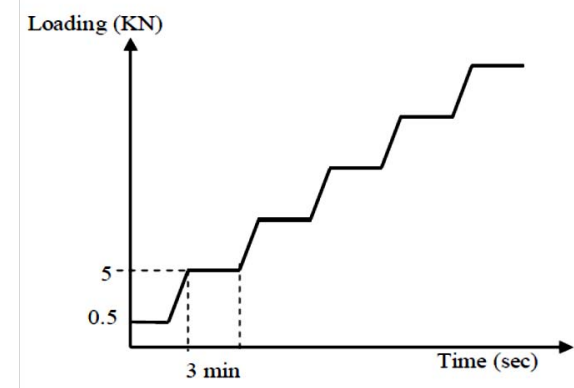

Fig. 4. Stepwise Loading conditions.

\section{RESUlt AND DISCUSSION}

\section{A. Signal Strength Analysis}

In this paper, the main parametric correlation that will be emphasized is, signal strength versus time. This is the main part of intensity analysis which is related to the damages parameter besides the amplitude other component.

The AE signal strength data recorded during the loading phase are extracted for each beam and analyzed by channel sensors basis. The selected channels are according to the maximum value of cumulative signal strength and the values were plotted as indicate in Fig. 5.

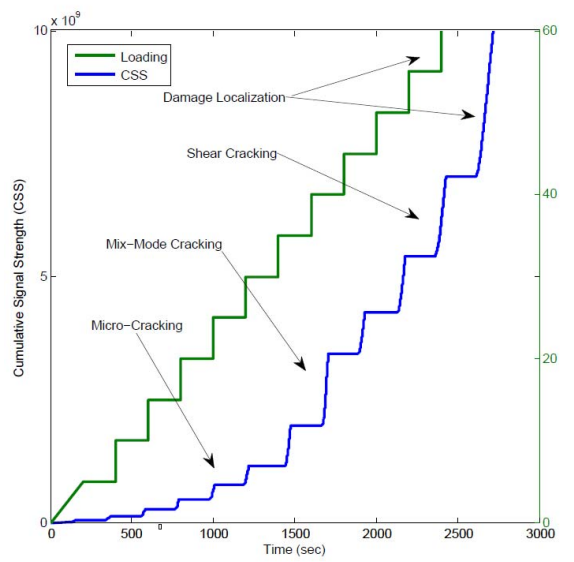

Fig. 5. Relationship on the CSS and Stepwise loading.

Fig. 5 indicated the relationship of amount of signal strength due to the stepwise loading condition corresponding to the real time testing.

Through the observation in Fig. 5 the signal strength values were increase slightly during the initial stage within $500 \mathrm{sec}$ up to $1500 \mathrm{sec}$. However, the values start to increase 
dramatically until at end of the graph line. One possible explanation for this occurrence could be caused by the high attenuating property of a heterogonous material like concrete and the crack formation.

During the initial of loading within $500 \mathrm{sec}$ to $1000 \mathrm{sec}$ the beams indicated the micro-cracking stage. This type of cracking are normally cannot view by naked eyes, but however when the loading are increase up to $60 \%$, the beam will show the mix-mode cracking which is involving the flexural and shear cracking. This indicated in Fig 5, where the mix mode cracking occur during $1700 \mathrm{sec}$ to $2400 \mathrm{sec}$. When the loading get to $80 \%$ of increasing, the next step of crack is shear cracking. This type of cracking is the final stages of cracking propagation as presented in fig 5 within $2400-2600$ sec.

The damaged localization occurred right after shear cracking process and is considered as inactive phase, where a significance increment in AE hit and energy rates are always formed during shear crack. This trend is clearly reflected in the intensity analysis chart as well

\section{B. Intensity Analysis Method}

$\mathrm{S}_{\mathrm{r}}$ graph presented in Fig. 6 show the severity value increases gradually during the increment values of the signal strength at the initial stage.

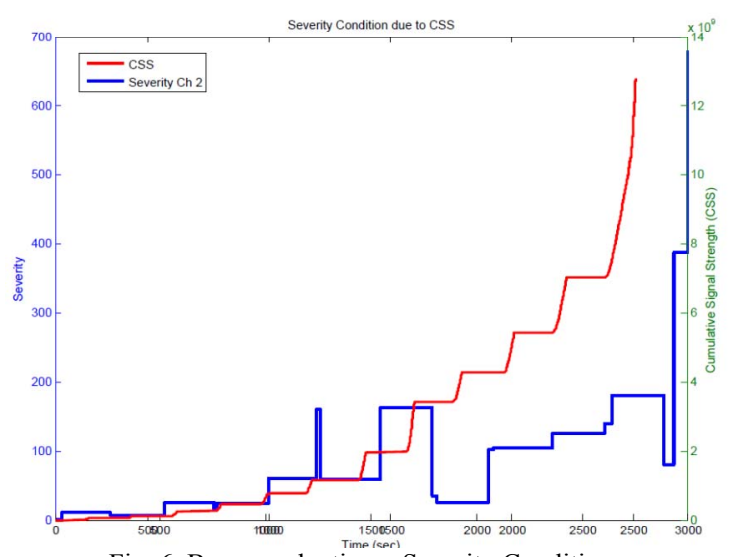

Fig. 6. Beam evaluation - Severity Condition.

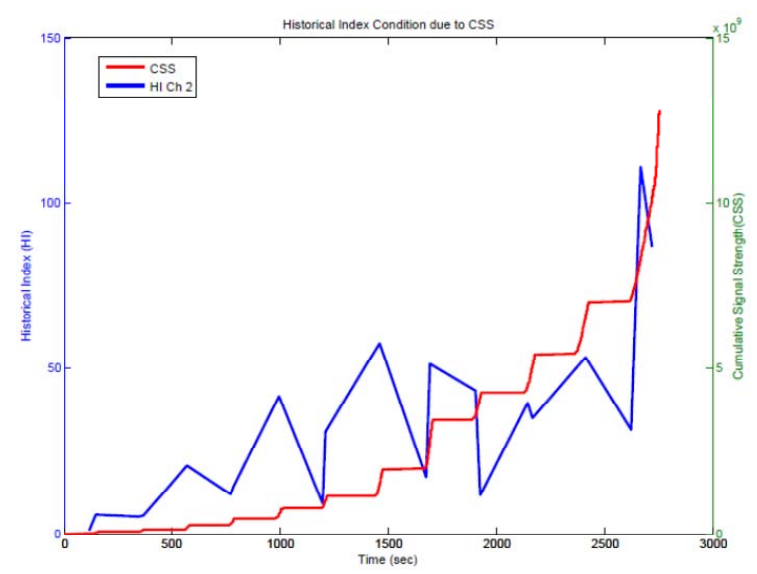

Fig. 7. Beam evaluation - Historical Index.

However, it shows dramatically increment when the cumulative signal strength reach the maximum value.

The severity values for this investigation are between 100,000 and 100 million. These ranges of values are similar with the previous research and this signifies the release of the high energy content in the beam specimens, where as the damages are continuously being more serious till to failure stage such as breakage of the concrete structure and shear failure [17].

Historical index is a good indicator of the onset for significant damage, as indicated in Fig. 7. This figure illustrated the relationships between $\mathrm{HI}$ and CSS functions of time and similar to the $S_{\mathrm{r}}$ condition figures. The characteristic of these figures are almost similar due to the condition of the reinforced concrete beam compared to the fiber reinforced concrete, perhaps the features of the slope HI and CSS are higher than normal concrete structure. Referring to these figures, there is a rapid increase in the slope of the CSS curve within intervals of $1000-2000$ s and at the final stage of the testing within $2500-3000$ s. These outcomes are almost similar to the previous research work by [17]. Throughout the time of interval, the values of $\mathrm{HI}$ are highly peak correspond to the slope increase of the CSS curve value. Upon to that matter, the previous research has discussed that peaks of HI and CSS curve can be employed to discriminate and identify the possible damaged mechanism and onset of failure [14], [17].

Therefore, the intensity analysis charts are divided into five zones (A, B, C, D, E) in order to classify the damage level of the beam specimens. According to the cumulative signal strength analysis, it was carried out based on the number of load phases. In this investigation, the total numbers of load phases are eleven and it was found that the charts plotted for all beam specimens were represented almost similar to the trend of phase distribution in the zones as presented in Fig 8.

Besides that, the theoretical calculations were pointed in this investigation and the beams are begins to show hairline cracks at the tensile portion of the specimens at about $12 \%$ of the ultimate load and about $50 \%$ to $70 \%$ of ultimate load the intensity values appear to imply the flexural and shear cracks.

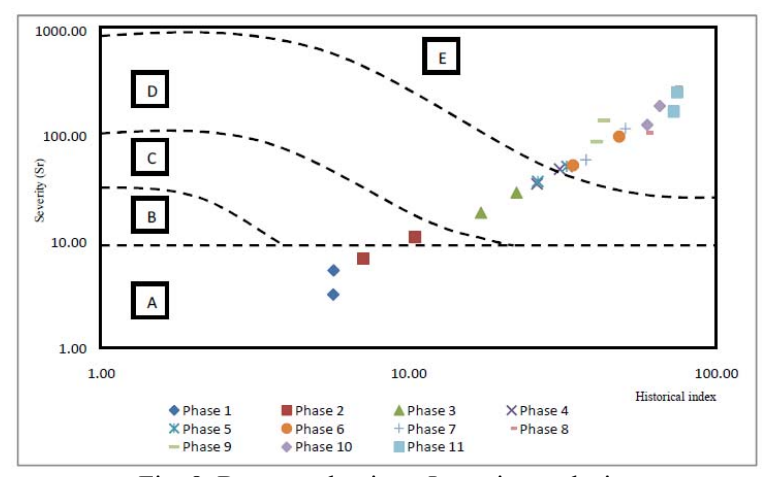

Fig. 8. Beam evaluation - Intensity analysis.

During this time, the intensity analysis values indicate the sufficient warning for estimation the severity of damage in the beams. Therefore, the entire Zones as indicate in the Fig 8 are proposed based on the calculation and brief observation above and it is also related to the AE signal strength data. This chart is valid for evaluating the reinforced concrete beams of the same dimension and subjected to the similar load condition.

\section{CONCLUSION}

In a nut shell, the integrity of concrete structure members 
can be sufficiently quantified by using the intensity analysis and this method shows great potential in becoming an effective tool for evaluation and continuous monitoring for all fields of structure without considering any type of size or material.

\section{ACKNOWLEDGMENT}

The authors are grateful to all technician Structure staff at Universiti Sains Malaysia for helping during the experimental work till completed the work.

\section{REFERENCES}

[1] A. Berkovits and D. Fang. "Study of fatigue crack characteristics by acoustic emission," Engineering Fracture Mechanics, vol. 51, no. 3, pp 401-409, 1995.

[2] Z. Liu, "Evaluation of Reinforced Concrete Beam Using Cyclic Load Teat, Acoustic Emission and Aousto-Ultrasonics, ’PhD Thesis, University of South Carolina, 2007.

[3] X. Luo, H. Haya, T. Inaba, T. Shiotani, and Y. Nakanishi, "Damage evaluation of railway structures by using train-induced AE," Construction and Building Materials, vol. 18, no. 3, pp. 215-223, 2004.

[4] G. Song, and et al. "Concrete structural health monitoring using embedded piezoceramic transducers," Smart Materials and Structures, vol. 16, no. 4, pp. 959, 2007.

[5] A. Mahmood,"Structural Health Monitoring Using Non Destructive Testing of Concrete," Master Thesis, Rourkela, National Institute of Technology, 2008.

[6] N. Ativitavas,"Acoustic emission signature analysis of failure mechanisms in fiber-reinforced plastic structures," PhD thesis United States -- Texas, The University of Texas at Austin, 2002.

[7] K. Matsuyama, M. Yamada, and M. Ohtsu, "On-site measurement of delamination and surface crack in concrete structure by visualized NDT," Construction and Building Materials, vol. 24, no. 12, pp. 2381-2387, 2010.

[8] ASTM E976, "Standard Guide for determining the reproducibility of Acoustic Emission sensor respone," The American Society for Testing and Materials, 1999.

[9] N. Muhamad Bunnori, "Acoustic Emission Technique For The Damage Assessment of Reinforced Concrete Structure." PhD Thesis, Cardiff, University of Cardiff, 2008.

[10] A. Nair and C. S. Cai, "Acoustic emission monitoring of bridges: Review and case studies," Engineering Structures, vol. 32, no. 6, pp.1704-1714, 2010.

[11] S. Shahidan, N. Md Nor, and N. Muhamad Bunnori,"Overview of Moment Tensor Analysis of Acoustic Emission Signal in Evaluation Concrete Structure," 2011 IEEE $7^{\text {th }}$ International Colloquium on Signal Processing and Its Applications March 4-6, Penang, Malaysia, 2011

[12] D. G. Aggelis. "Classification of cracking mode in concrete by acoustic emission parameters," Mechanics Research Communications, vol. 38 , no. 3 , pp. $153-157,2011$.

[13] N. M. Nor, N. M. Bunnori, A. Ibrahim, S. Shahidan, and S. N. Mat Saliah, "An observation of noise intervention into acoustic emission signal on concrete structure, " 2011 IEEE 7th International Colloquium on Signal Processing and Its Applications March 4-6, Penang, Malaysia, 2011

[14] L. Golaski, G. Pawel, and O. Kanji, "Diagnostic of Reinforced Concrete Bridge by Acoustic Emission," J. Acoustic Emission 20,2002.

[15] R. S. Gostautas, G. Ramirez, R. J. Peterman, and D. Meggers. "Acoustic Emission Monitoring and Analysis of Glass Fiber-Reinforced Composites Bridge Decks," Journal of Bridge Engineering, vol. 10, no. 6, pp. 713-721, 2005.

[16] S. Degala, P. Rizzo, K. Ramanathan, and K. A. Harries, "Acoustic emission monitoring of CFRP reinforced concrete slabs," Construction and Building Materials, vol. 23, no. 5, pp. 2016-2026, 2009.

[17] E. Proverbio, "Evaluation of deterioration in reinforced concrete structures by AE technique," Materials and Corrosion, vol. 62, no. 2, pp. 161-169, 2011

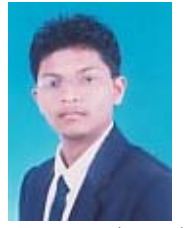

Shahiron Shahidan ( M.Sruct) was born in northern area of Malaysia on 23rd March 1983. His first degree at University Industri Selangor (UNISEL) Malaysia in Bach of Civil Eng(Hons) 2007. Then he continued deeply in Master of Structural Engineering (M.Struct) at Universiti Putra Malaysia in 2009 and currently his pursuing in $\mathrm{PhD}$ level at Universiti Sains Malaysia in Structural Health Monitoring. He was a tutor since 2007 at Universiti Tun Hussien Onn Malaysia in southern area of Malaysia and his favorite subject teaching is Structural Concrete and Structure Analysis.

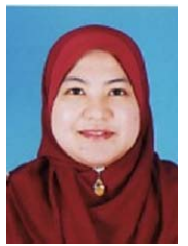

Norazura Muhamad Bunnori $(\mathrm{PhD})$ has been involved in Acoustic Emission (AE)technique since 2004 while she was pursuing her PhD study at Cardiff University, Wales, UK. She was graduated from Cardiff University in 2008 and continues with the AE research area in Universiti Sains Malaysia (USM), Malaysia. Currently she is working as a Senior Lecturer at School of Civil Engineering, Universiti Sains Malaysia (USM) since 2009. The research covered several topics of $\mathrm{AE}$ applications and analysis (quantitative and qualitative).

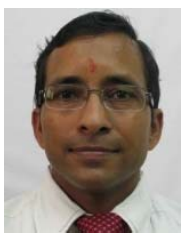

Neeraj Bhardwaj $(\mathrm{PhD})$ is involved in vibration of structure since 1999. While he was pursuing his $\mathrm{PhD}$ at India Institute of Technology Roorkee, India in 1996. Since 1999 onwards he involve in teaching and research and also have published international journal, conference paper and a author of the Engineering Mathematic Books. Presently he is a Senior Lecturer at School of Civil Engineering, Universiti Sains Malaysia (USM) and the research area covered several topics of $\mathrm{AE}$ vibration and mathematical analysis.

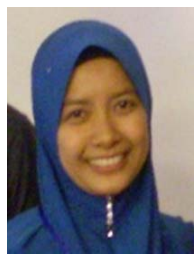

Noorsuhada Md Nor is a PhD student in Faculty of Civil Engineering, Universiti Teknologi MARA (UiTM), Structural division. She graduated in Master of Science (Civil Engineering) from Universiti Teknologi Malaysia (UTM) in 2005. Currently, she is actively doing research on acoustic emission, damage assessment and fatigue of reinforced concrete structure. Previously she involved in research on structural material and participated in many competitions as well as Invention, Innovation and Design (IID) and International Invention, Innovation and Technology Exhibition (ITEX); which bestoweda total ofmedals. In order to improve her achievement and performance, she starts to active in publication of papers especially in Acoustic Emission (AE) technique.

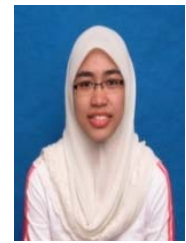

Siti Ramziah Basri is a student from School of Civil Engineering, Universiti Sains Malaysia. She was born in October 1988 and getting her first degree, B.Eng (Civil) (Hons) in USM in September 2011. She currently now pursuing her study in master level at USM which the study focus on structural damage evaluation by using numerical method. In her undergraduate study, she was being exposed to NDT study in her final year project. Her undergraduate research is focus on evaluation of reinforced concrete damage by using acoustic emission under the supervision of Dr. Norazura Muhamad Bunnori.

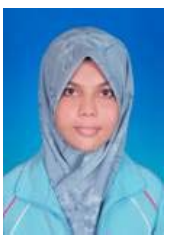

Sakhiah Abdul Kudus is a student from School of Civil Engineering, Universiti Sains Malaysia. She was born in April 1988 and getting her first degree, B.Eng (Civil) (Hons) in USM in September 2011. She currently now pursuing her study in master level at USM which the study focus on structural damage evaluation by using numerical method. In her undergraduate study, she was being exposed to NDT study in her final year project. Her undergraduate research is focus on real time monitoring of reinforced concrete beam by using acoustic emission technique under the supervision of Dr. Norazura Muhamad Bunnori. 